\title{
Ullmann Reaction of Aryl Chlorides on Various Surfaces and the Application in Stepwise Growth of 2D Covalent Organic Frameworks
}

Ke Ji Shi, ${ }^{\dagger}$ Ding Wang Yuan, ${ }^{\dagger}$ Cheng Xin Wang, ${ }^{\dagger}$ Chen Hui Shu, ${ }^{\dagger}$ Deng Yuan Li, ${ }^{\dagger}$ Zi Liang Shi, $\S$ Xin Yan Wu, ${ }^{\dagger}$ Pei Nian Liu ${ }^{*}+\dagger$

Shanghai Key Laboratory of Functional Materials Chemistry, Key Lab for Advanced Materials and Institute of Fine Chemicals, East China University of Science and Technology, 130 Meilong Road, Shanghai, 200237, China

* School of Materials Science and Engineering, Hunan University, Changsha, 410082, China

s Center for Soft Condensed Matter Physics \& Interdisciplinary Research, Soochow University, No.1 Shizi Street, Su-zhou, Jiangsu Province, 215006, P. R. China liupn@ecust.edu.cn

\section{Supporting Information}

1. Synthesis of organic molecules..........................................S2

2. General procedure for the STM experiment...................................S3

3. General procedure for the calculation.....................................S4

4. Supplemental STM images............................................... 55

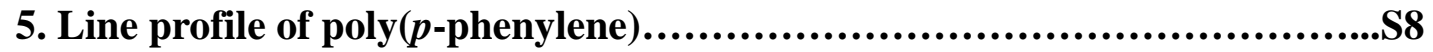

6. DFT-calculated lengths................................................S9

7. Calculated states of the dechlorination reaction of phenyl chloride on $\mathrm{Cu}(111)$,

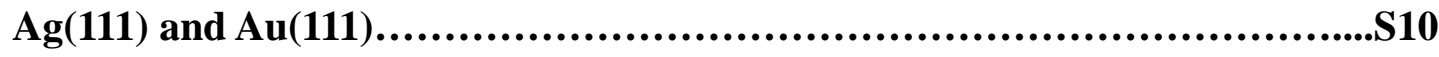

8. Calculated debromination reaction of phenyl bromide on $\mathrm{Cu}(111)$............S11

9. Reference.............................................................S12

10. Copies of ${ }^{1} \mathrm{H}$ and ${ }^{13} \mathrm{C}$ NMR spectra for the molecules........................S13 


\section{Synthesis of organic molecules}

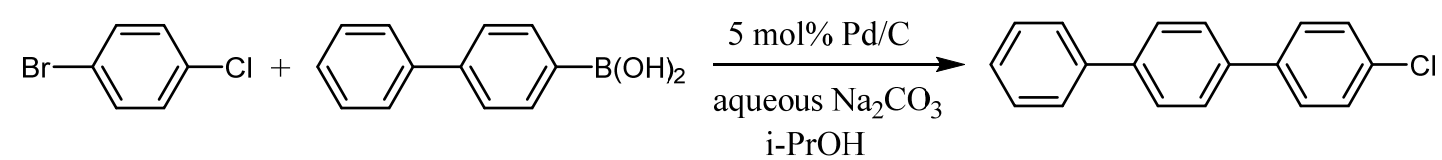

4-Chloro-p-terphenyl (CTP). ${ }^{1}$ To a solution of 1-bromo-4-chlorobenzene (2.0 $\mathrm{mmol})$, 4-biphenylboronic acid $(3.0 \mathrm{mmol})$ and $\mathrm{Pd} / \mathrm{C}(5 \% \mathrm{Pd}$ basis, $106 \mathrm{mg})$ in $i$-PrOH $(6 \mathrm{~mL})$ was added $2 \mathrm{M}$ degassed aqueous $\mathrm{Na}_{2} \mathrm{CO}_{3}$ solution $(4 \mathrm{~mL})$ under $\mathrm{N}_{2}$ atmosphere. The resulting mixture was stirred at $80^{\circ} \mathrm{C}$ for $12 \mathrm{~h}$. After cooling to room temperature, the mixture was filtered and the solid residue was washed with ethyl acetate $(5 \times 30 \mathrm{~mL})$ and petroleum ether $(3 \times 30 \mathrm{~mL})$. The resulting solid residue was purified by sublimation twice in vaccum to give the product as white solid in $15 \%$ yield (79 mg). Mp: $223-225{ }^{\circ} \mathrm{C} ;{ }^{1} \mathrm{H}$ NMR (400 MHz, $\left.\mathrm{CDCl}_{3}, 25{ }^{\circ} \mathrm{C}\right) \delta$ 7.35-7.48 (m, 5H), 7.55-7.69 (m, 8H); ${ }^{13} \mathrm{C} \mathrm{NMR}\left(100.6 \mathrm{MHz}, \mathrm{CDCl}_{3}, 25{ }^{\circ} \mathrm{C}\right) \delta 127.2,127.5,127.6$, 127.7, 128.4, 129.0, 129.1, 133.6, 139.0, 139.3, 140.6, 140.7; HRMS (EI, TOF) calcd for $\mathrm{C}_{18} \mathrm{H}_{13} \mathrm{Cl}^{+}[\mathrm{M}]^{+}:$264.0706, found: 264.0704 .

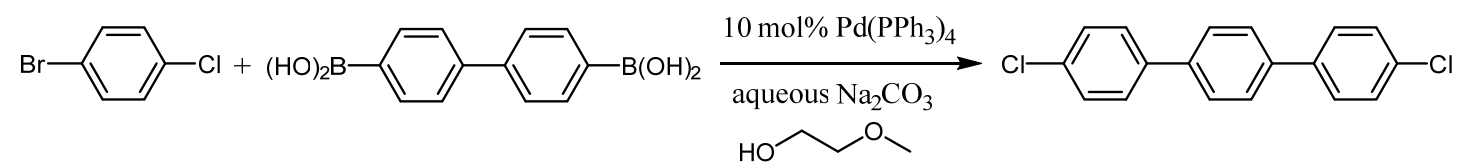

4, 4"-Dichloro-p-terphenyl (DCTP). ${ }^{2}$ To a solution of 1-bromo-4-chlorobenzene (7.2 mmol), [1,1'-biphenyl]-4,4'-diyldiboronic acid $(3.0 \mathrm{mmol})$ and $\mathrm{Pd}\left(\mathrm{PPh}_{3}\right)_{4}(0.3$ mmol, $10 \mathrm{~mol} \%)$ in 2-methoxyethanol $(30 \mathrm{~mL})$ was added $2 \mathrm{M}$ degassed aqueous $\mathrm{Na}_{2} \mathrm{CO}_{3}$ solution $(6 \mathrm{~mL})$ under $\mathrm{N}_{2}$ atmosphere. The resulting mixture was stirred at reflux for $24 \mathrm{~h}$. After cooling to room temperature, the mixture was filtered and the solid residue was washed with ethyl acetate $(5 \times 30 \mathrm{~mL})$ and petroleum ether $(3 \times 30$ $\mathrm{mL}$ ). The solid residue was then purified by sublimation twice in vaccum to give the product as white solid in $12 \%$ yield $(107 \mathrm{mg})$. Mp: $285-288^{\circ} \mathrm{C} ;{ }^{1} \mathrm{H}$ NMR (400 MHz, $\left.\mathrm{CDCl}_{3}, 25{ }^{\circ} \mathrm{C}\right) \delta 7.43(\mathrm{~d}, J=8.6 \mathrm{~Hz}, 4 \mathrm{H}) ; 7.56(\mathrm{~d}, J=8.6 \mathrm{~Hz}, 4 \mathrm{H}), 7.64(\mathrm{~s}, 4 \mathrm{H}) ;{ }^{13} \mathrm{C}$ NMR (100.6 MHz, $\left.\mathrm{CDCl}_{3}, 25{ }^{\circ} \mathrm{C}\right) \delta 127.6,128.4,129.2,133.7,139.1,139.4$; HRMS 
(EI, TOF) calcd for $\mathrm{C}_{18} \mathrm{H}_{12} \mathrm{Cl}_{2}^{+}[\mathrm{M}]^{+}:$298.0316, found: 298.0319 .

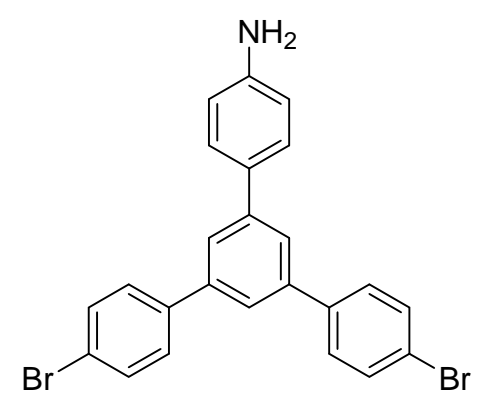<smiles>Clc1ccc(-c2cc(-c3ccc(Br)cc3)cc(-c3ccc(Br)cc3)c2)cc1</smiles>

4,4"'-Dibromo-5'-(4-chlorophenyl)-1,1':3',1"'-terphenyl (DBCTP). In a three-necked round-bottom flask, anhydrous copper(II) chloride (1.2 mmol), tert-butyl nitrite $(1.5 \mathrm{mmol})$, and anhydrous acetonitrile $(4 \mathrm{~mL})$ were added. The resulting mixture was stirred rapidly and warmed to $65{ }^{\circ} \mathrm{C}$. 4"-Bromo-5'-(4-bromophenyl)-[1,1':3',1"-terphenyl]-4-amine ${ }^{3}$ (1 mmol) in acetonitrile was slowly added over a period of $5 \mathrm{~min}$ to the reaction solution. After $10 \mathrm{~min}$, the reaction solution was cooled to room temperature and then poured into $20 \mathrm{~mL}$ of $20 \%$ aqueous hydrochloric acid and extracted with $20 \mathrm{~mL}$ of ethyl ether, and the organic layer was washed with $20 \mathrm{~mL}$ of $20 \%$ aqueous hydrochloric acid. The resulting ether solution was dried over anhydrous magnesium sulfate and the ethyl ether was removed under reduced pressure after filtration, then the residue passed through flash column chromatography (petroleum ether) on silica gel to afford the products as white solid. Mp: $239-241{ }^{\circ} \mathrm{C} ;{ }^{1} \mathrm{H}$ NMR $\left(\mathrm{CDCl}_{3}, 400 \mathrm{MHz}\right) \delta$ 7.44-7.55 (6H, m), 7.59-7.62 $(6 \mathrm{H}, \mathrm{m}), 7.69(3 \mathrm{H}, \mathrm{s}) ;{ }^{13} \mathrm{C} \mathrm{NMR}\left(\mathrm{CDCl}_{3}, 100 \mathrm{MHz}\right) \delta 122.2,125.0,125.2,128.7$, 129.0, 129.2, 132.1, 132.2, 134.0, 139.3, 139.8, 141.6; HRMS (EI, TOF) calcd for $\mathrm{C}_{24} \mathrm{H}_{15} \mathrm{Br}_{2} \mathrm{Cl}^{+}[\mathrm{M}]^{+}:$495.9229, found: 495.9228.

\section{General procedure for the STM experiment}

The STM experiments were performed in a commercial UHV system (base pressure 2 $\times 10^{-10}$ mbar) equipped with a variable temperature scanning tunneling microscope (SPECS, Aarhus 150), a molecular evaporator, and standard facilities for sample preparation. The single-crystalline $\mathrm{Cu}(111), \operatorname{Ag}(111), \mathrm{Au}(111)$ surfaces were cleaned 
by cycles of argon-ion sputtering and annealing. After thorough degas, the molecules CTP $\left(53{ }^{\circ} \mathrm{C}\right)$, DCTP $\left(96{ }^{\circ} \mathrm{C}\right)$ and DBCTP $\left(135^{\circ} \mathrm{C}\right)$ were deposited by thermal sublimation onto the corresponding substrates and annealed to the indicated temperature. The subsequent samples measurements were carried out at $\sim 110 \mathrm{~K}$.

\section{General procedure for the calculation}

The calculations were carried out in the framework of DFT by using the Vienna $\mathrm{Ab}$ Initio Simulation Package (VASP). ${ }^{4,5}$ The projector augmented wave method was used to describe the interaction between ions and electrons. ${ }^{6,7}$ We used the generalized gradient approximation (GGA) with Perdew-Burke-Ernzerhof(PBE) formulism to treat exchange-correlation interaction, ${ }^{8}$ and van der Waals (vdW) interactions were considered by using the DFT-D2 developed by Grimme. ${ }^{9}$ The structures were relaxed until the forces on all unconstrained atoms were $\leqslant 0.015 \mathrm{eV} / \AA$. All surfaces were modeled by four layered slabs separated by at least $20 \AA$ of vacuum, a $\mathrm{p}(5 \times 5)$ surface unit cell for $\mathrm{Au}(111), \mathrm{Ag}(111), \mathrm{Cu}(111)$ was used. Calculated lattice constants of 4.11 $\AA$ for $\mathrm{Au}, 4.14 \AA$ for $\mathrm{Ag}$, and $3.59 \AA$ for $\mathrm{Cu}$ were used (experimental lattice constants: 4.08, 4.09, and $3.61 \AA$ for $\mathrm{Au}, \mathrm{Ag}$, and $\mathrm{Cu}$, respectively). ${ }^{10}$ All calculations were done with a $2 \times 2 \mathrm{k}$-point sampling and a $450 \mathrm{eV}$ kinetic energy cutoff. 


\section{Supplemental STM images}

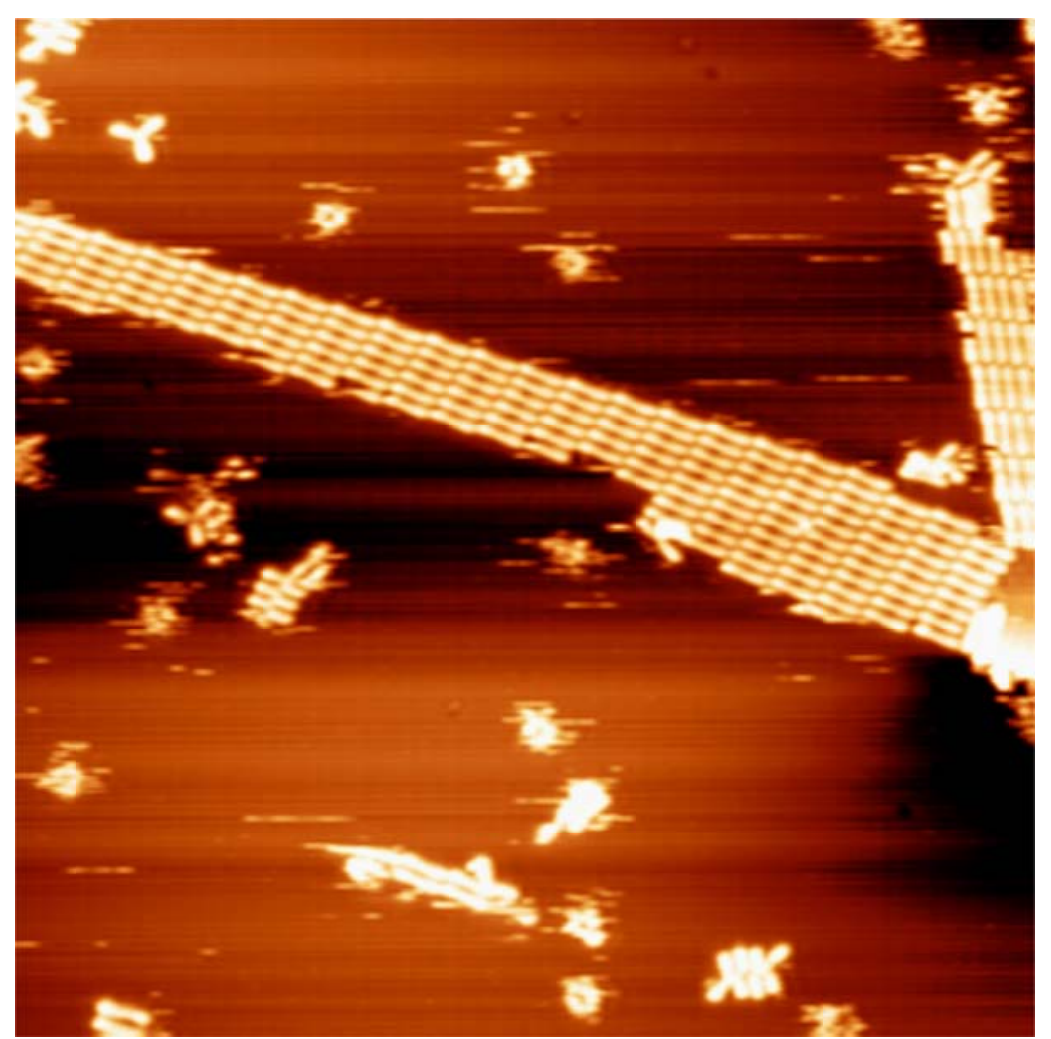

Figure S1. CTP on $\mathrm{Cu}(111)$ after annealing at $80{ }^{\circ} \mathrm{C}\left(65 \times 65 \mathrm{~nm}^{2},-1.6 \mathrm{~V},-0.09 \mathrm{nA}\right)$

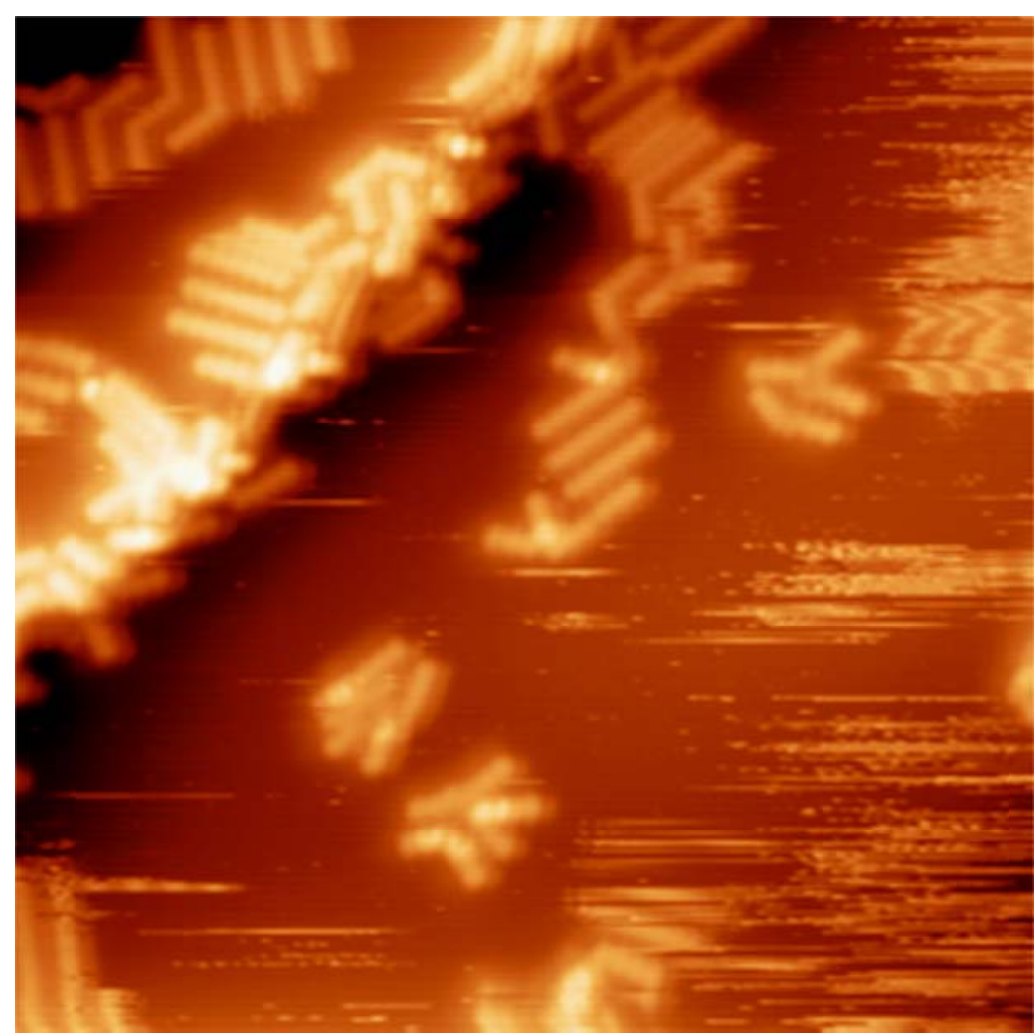

Figure S2. CTP on $\mathrm{Cu}(111)$ after annealing at $160{ }^{\circ} \mathrm{C}\left(26 \times 26 \mathrm{~nm}^{2},-1.5 \mathrm{~V},-0.07 \mathrm{nA}\right)$ 


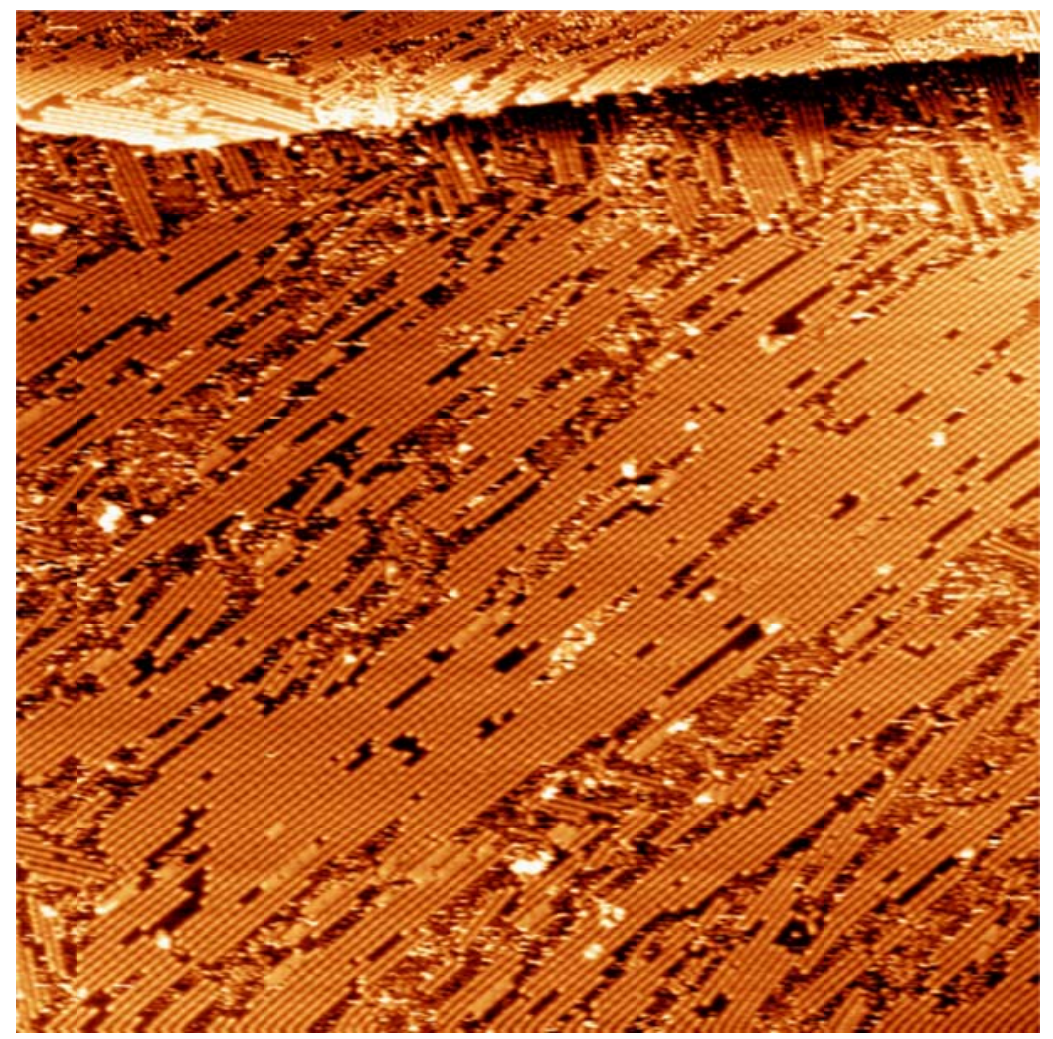

Figure S3. DCTP on $\mathrm{Cu}(111)$ after annealing at $80{ }^{\circ} \mathrm{C}\left(130 \times 130 \mathrm{~nm}^{2},-1.0 \mathrm{~V},-0.07\right.$ nA)

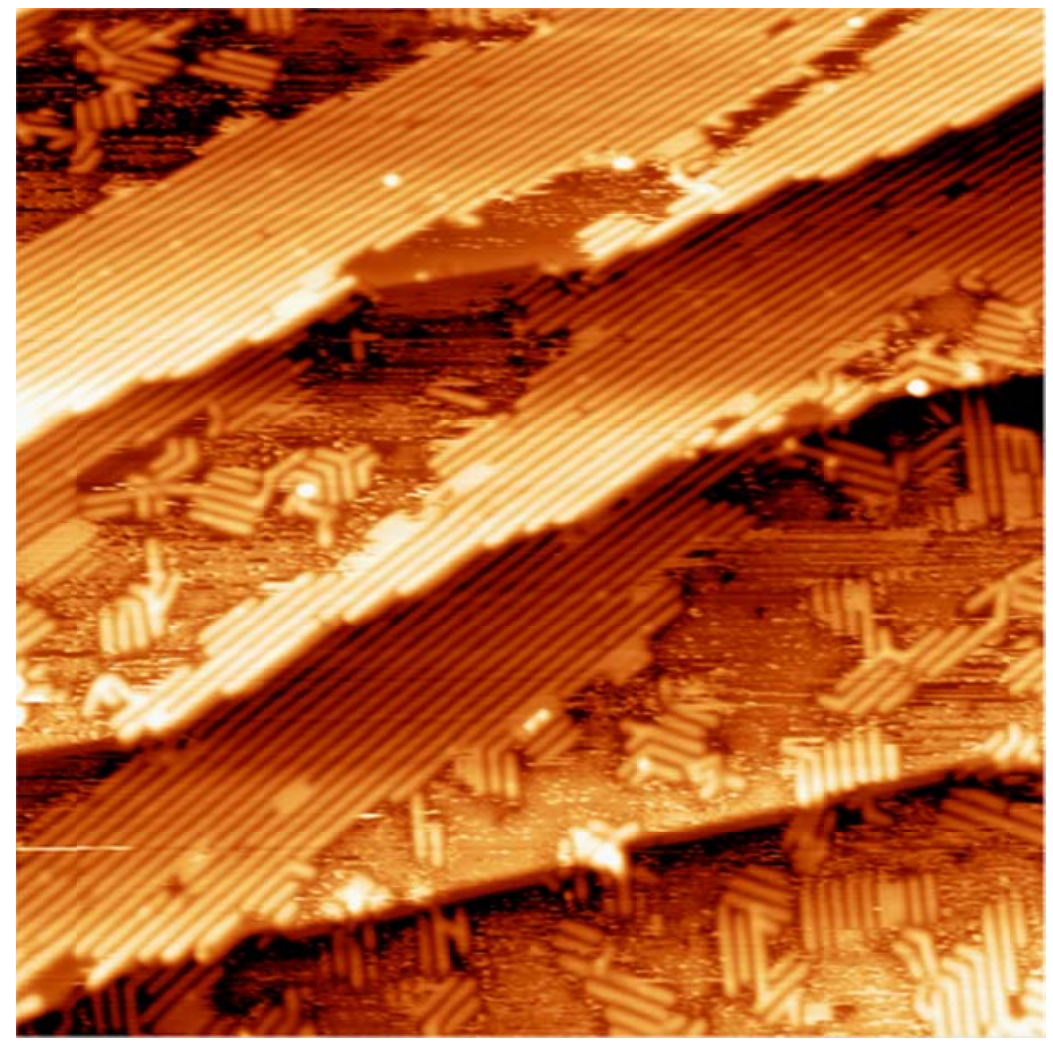

Figure S4. DCTP on $\mathrm{Cu}(111)$ after annealing at $160{ }^{\circ} \mathrm{C}\left(65 \times 65 \mathrm{~nm}^{2}, 1.0 \mathrm{~V}, 0.05 \mathrm{nA}\right)$ 


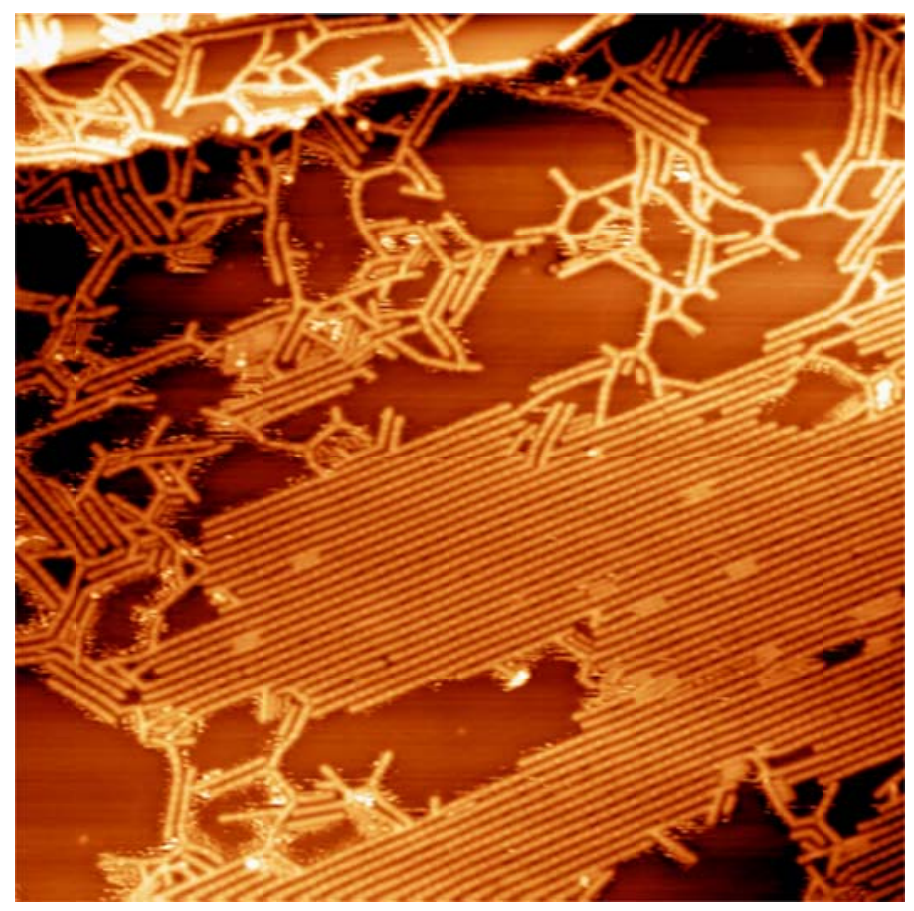

Figure S5. DCTP on $\operatorname{Ag}(111)$ after annealing at $120{ }^{\circ} \mathrm{C}\left(65 \times 65 \mathrm{~nm}^{2},-1.5 \mathrm{~V},-0.09\right.$ $\mathrm{nA}$ )

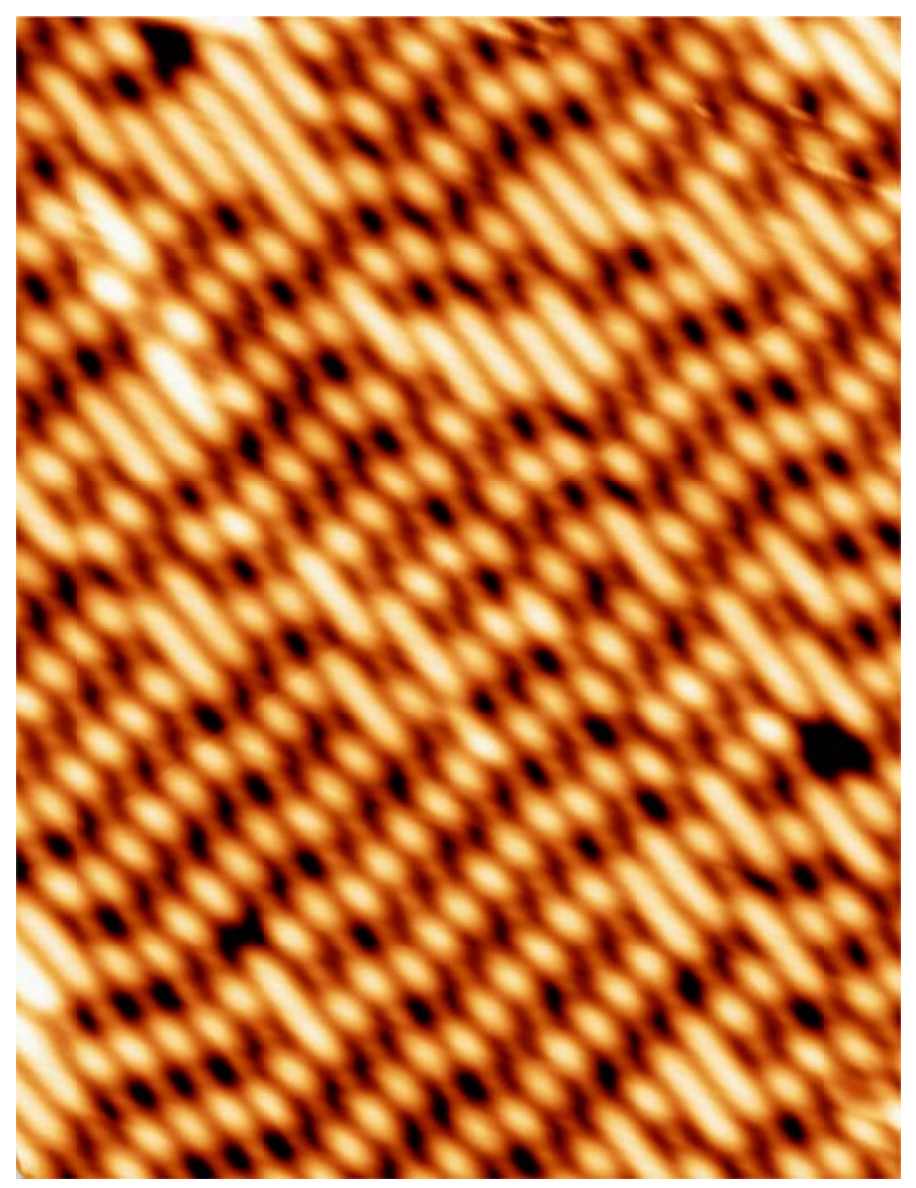

Figure S6. DCTP on $\operatorname{Ag}(111)$ after annealing at $120{ }^{\circ} \mathrm{C}\left(15 \times 20 \mathrm{~nm}^{2}, 2.5 \mathrm{~V}, 0.05 \mathrm{nA}\right)$ 


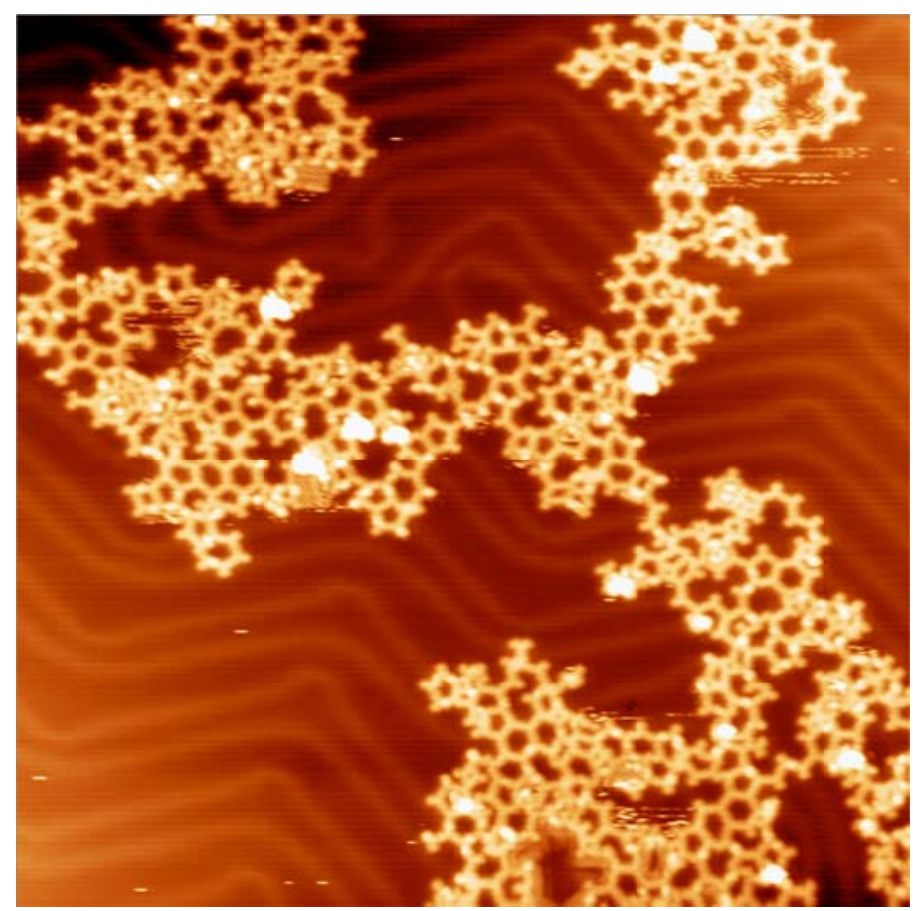

Figure S7. 1,3,5-tris(4-chlorophenyl)benzene and $\mathrm{Cu}$ on $\mathrm{Au}(111)$ after annealing at $300{ }^{\circ} \mathrm{C}\left(65 \times 65 \mathrm{~nm}^{2},-1.5 \mathrm{~V},-0.11 \mathrm{nA}\right)$

\section{Line profile of poly(p-phenylene)}
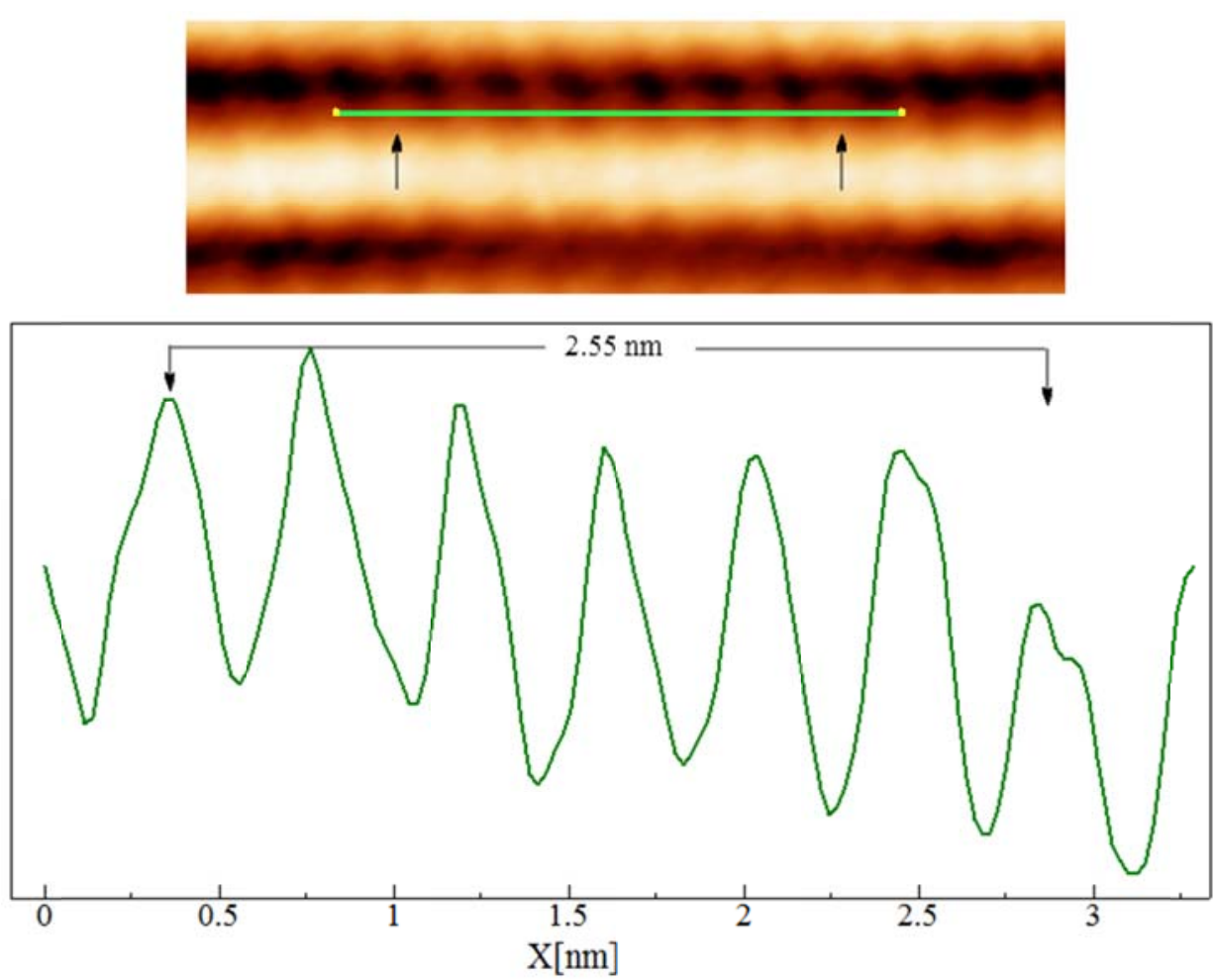

Figure S8. line profile of poly( $p$-phenylene) on $\mathrm{Cu}(111)$ 


\section{DFT-calculated lengths}

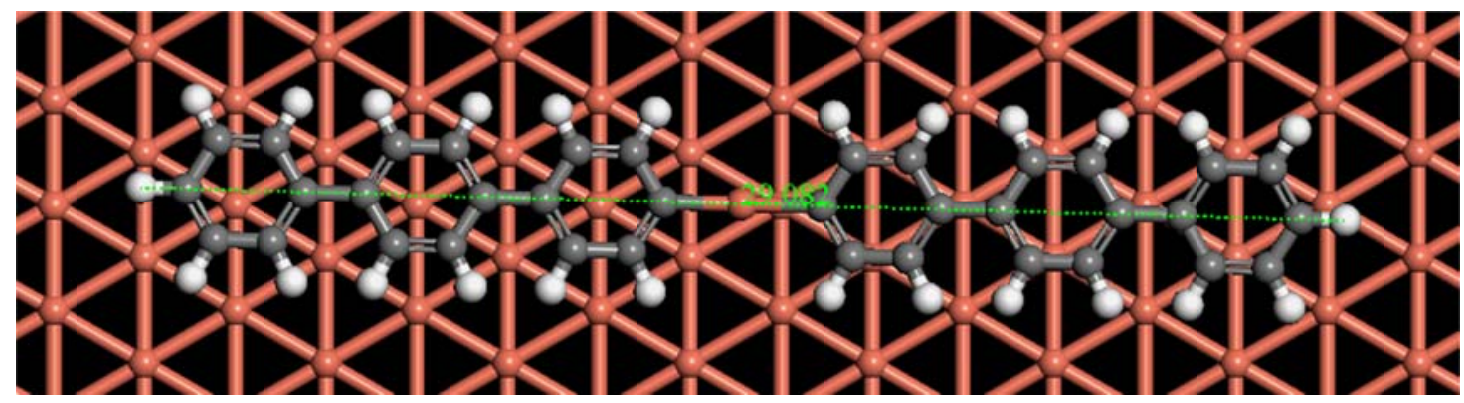

Figure S9. DFT-predicted length $(\AA)$ of the CTP intermediate on $\mathrm{Cu}(111)$

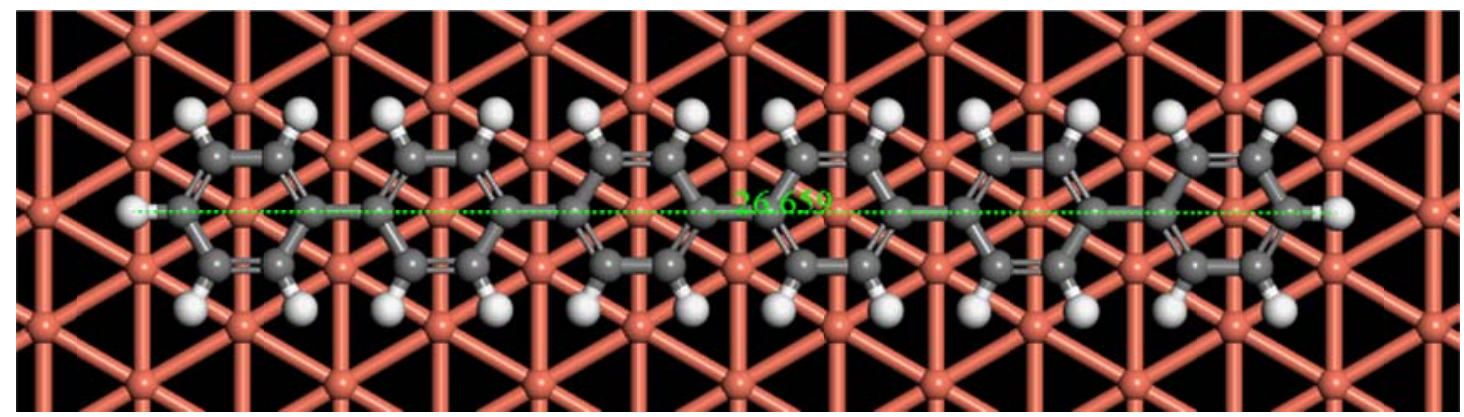

Figure S10. DFT-predicted length $(\AA)$ of the CTP coupling product on $\mathrm{Cu}(111)$

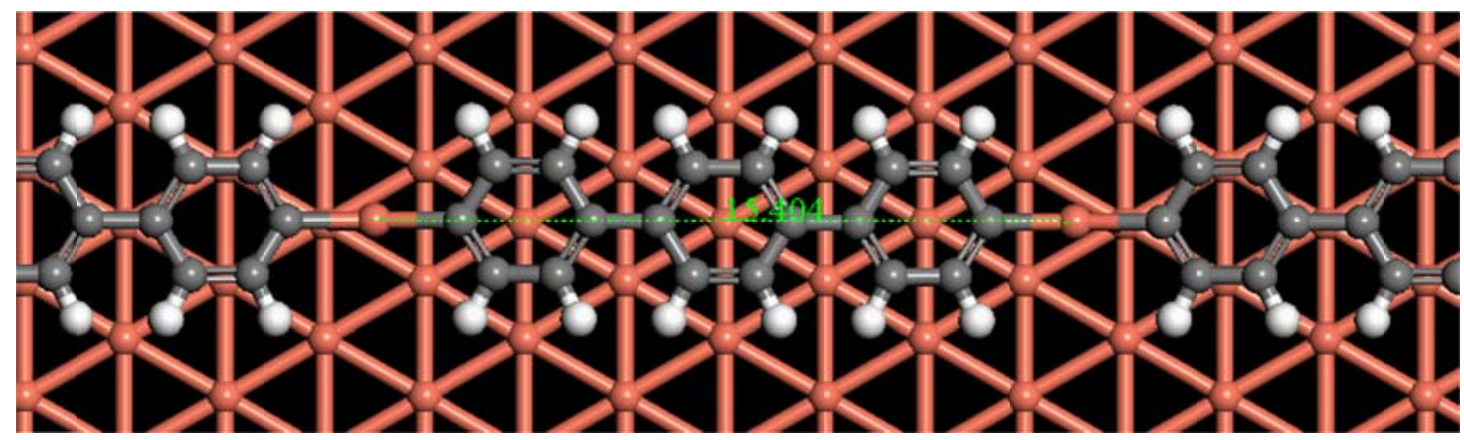

Figure S11. DFT-predicted length $(\AA)$ of the DCTP intermediate on $\mathrm{Cu}(111)$ 
7. Calculated states of the dechlorination reaction of phenyl chloride on $\mathrm{Cu}(111)$, Ag(111) and Au(111)

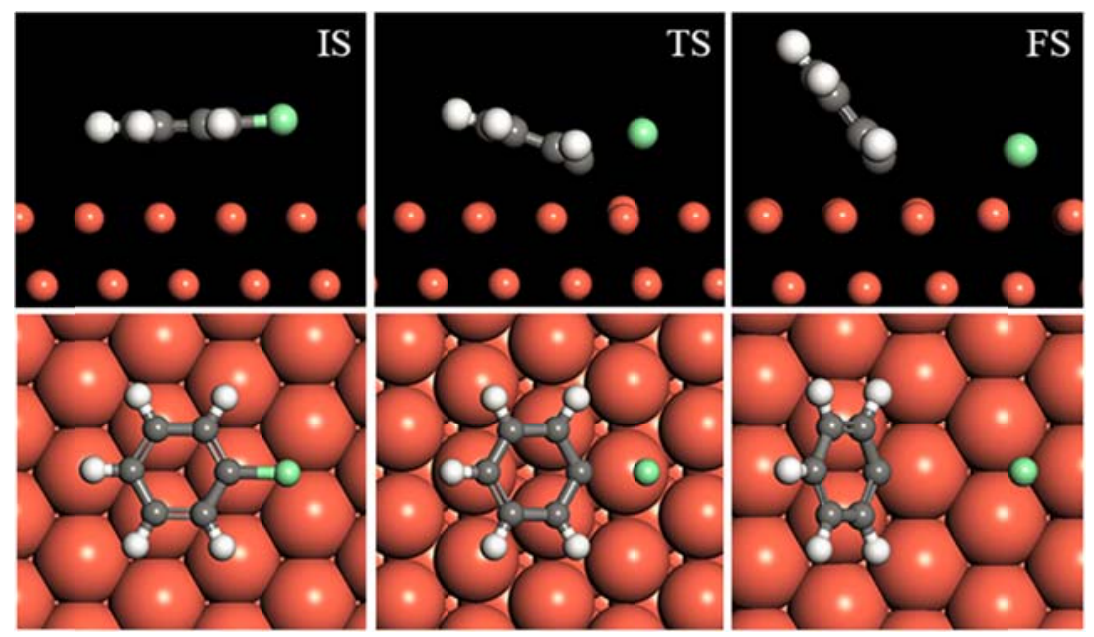

Figure S12. Top and side views of the initial state (IS), transition state (TS) and final state (FS) of the dechlorination reaction of phenyl chloride on $\mathrm{Cu}(111)$.

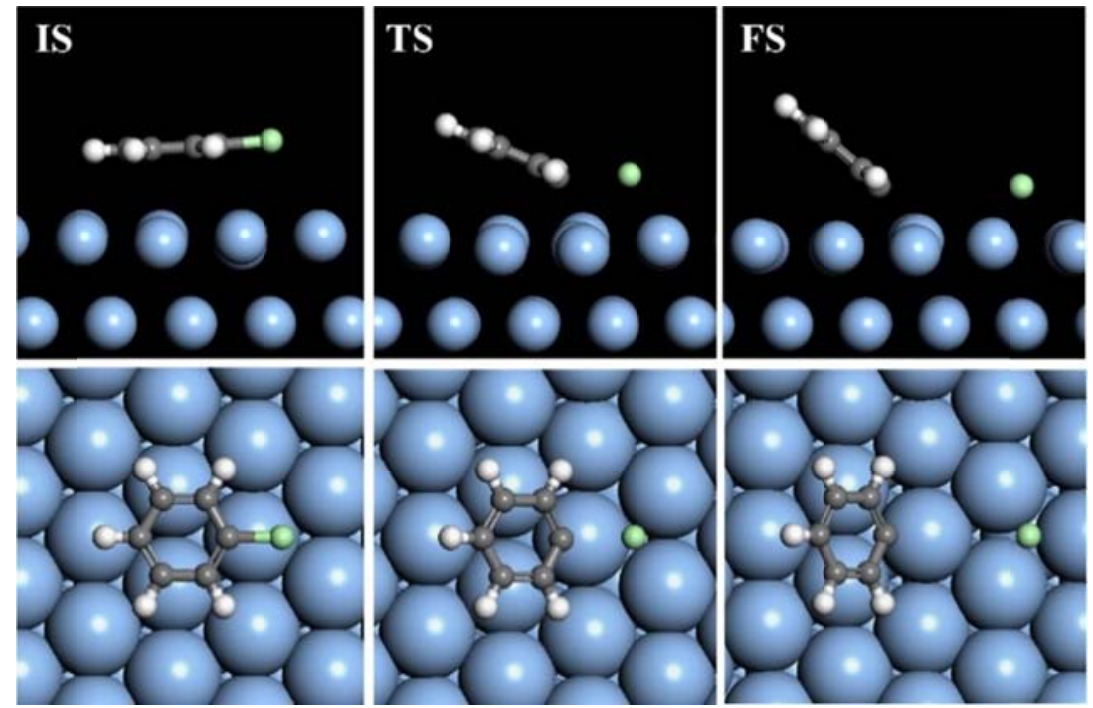

Figure S13. Top and side views of the initial state (IS), transition state (TS) and final state (FS) of the dechlorination reaction of phenyl chloride on $\mathrm{Ag}(111)$. 


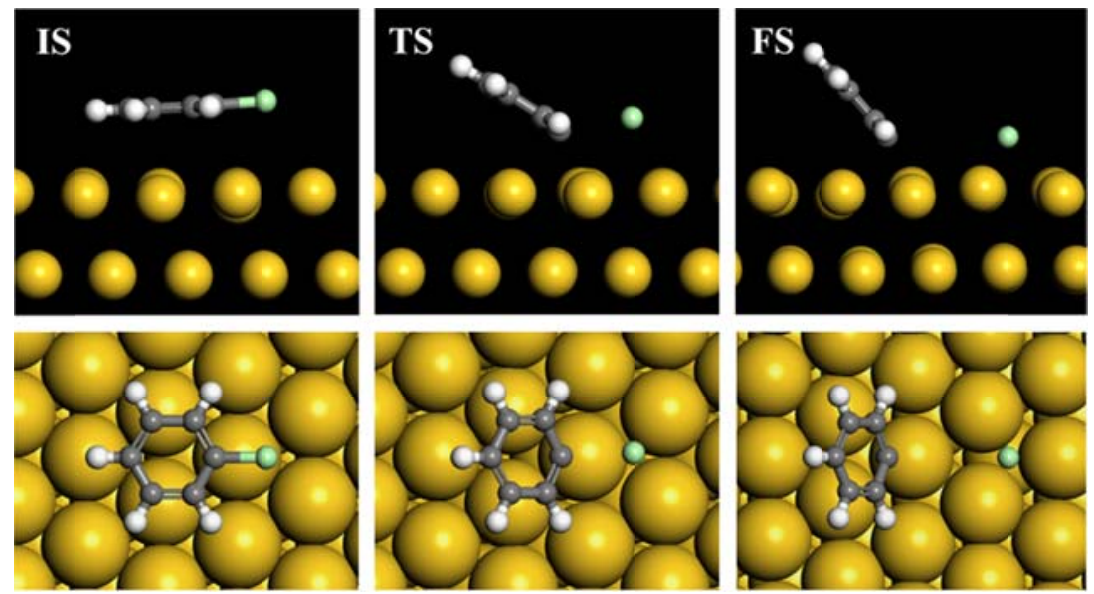

Figure S14. Top and side views of the initial state (IS), transition state (TS) and final state (FS) of the dechlorination reaction of phenyl chloride on $\mathrm{Au}(111)$.

\section{Calculated debromination reaction of phenyl bromide on $\mathrm{Cu}(111)$.}

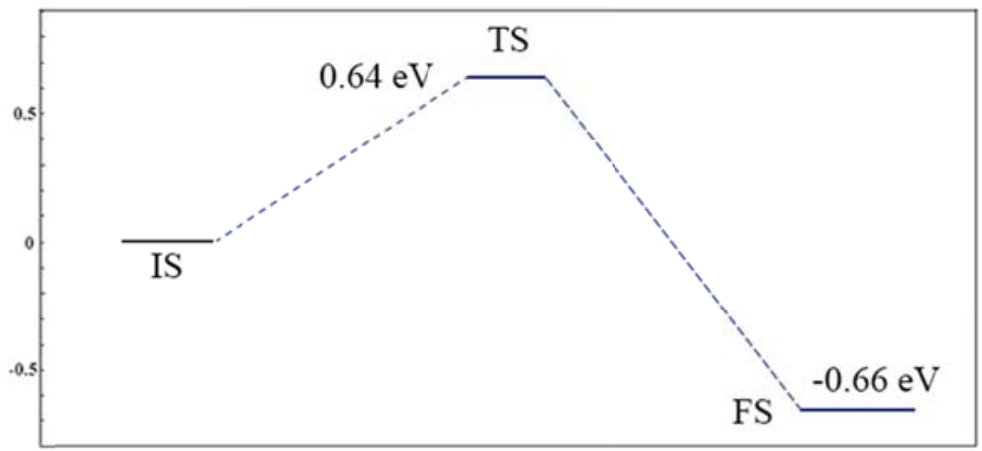

Figure S15. Calculated energy diagrams of debromination of phenyl bromide on $\mathrm{Cu}(111)$
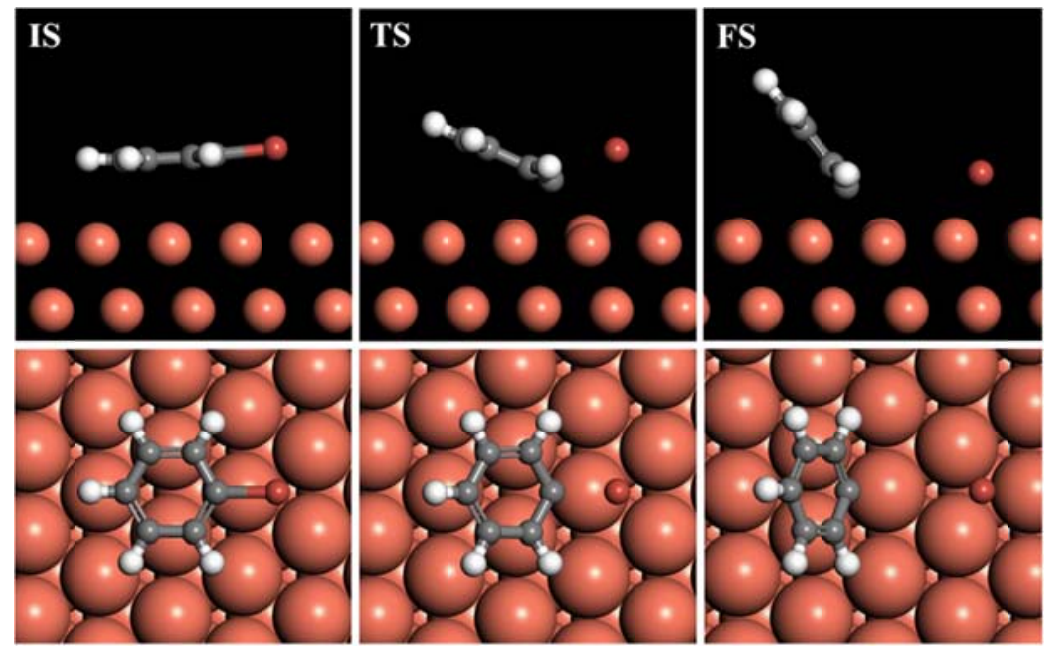

Figure S16. Top and side views of the initial state (IS), transition state (TS) and final state (FS) of the debromination reaction of phenyl bromide on $\mathrm{Cu}(111)$. 


\section{References}

(1) Taylor, R. H.; Felpin, F.-X. Org. Lett., 2007, 9, 2911.

(2) Hart, H.; Harada, K.; Du, C.-J. F. J. Org. Chem. 1985, 50, 3104.

(3) Eichhorn, J.; Strunskus, T.; Rastgoo-Lahrood, A.; Samanta, D.; Schmittel, M.; Lackinger, M. Chem. Comm., 2014, 50, 7680-7682.

(4) Kresse, G.; Hafner, J. Phys. Rev. B 1993, 48, 13115.

(5) Kresse, G.; Furthmüller, J. Phys. Rev. B 1996, 54, 11169.

(6) Blöchl, P. E. Phys. Rev. B 1994, 50, 17953.

(7) Kresse, G.; Joubert, D. Phys. Rev. B 1999, 59, 1758.

(8) Perdew, J. P.; Burke, K.; Ernzerhof, M. Phys. Rev. Lett. 1996, 77, 3865.

(9) Grimme, S. J. Comput. Chem. 2006, 27, 1787.

(10) Kittel, C. Introduction to Solid State Physics, 8th ed.; John Wiley \& Sons, Inc.: New York, 2005. 
10. Copies of ${ }^{1} \mathrm{H}$ and ${ }^{13} \mathrm{C}$ NMR spectra for the molecules

${ }^{1}$ H NMR of 4-chloro-1,1':4',1'-terphenyl (CTP).
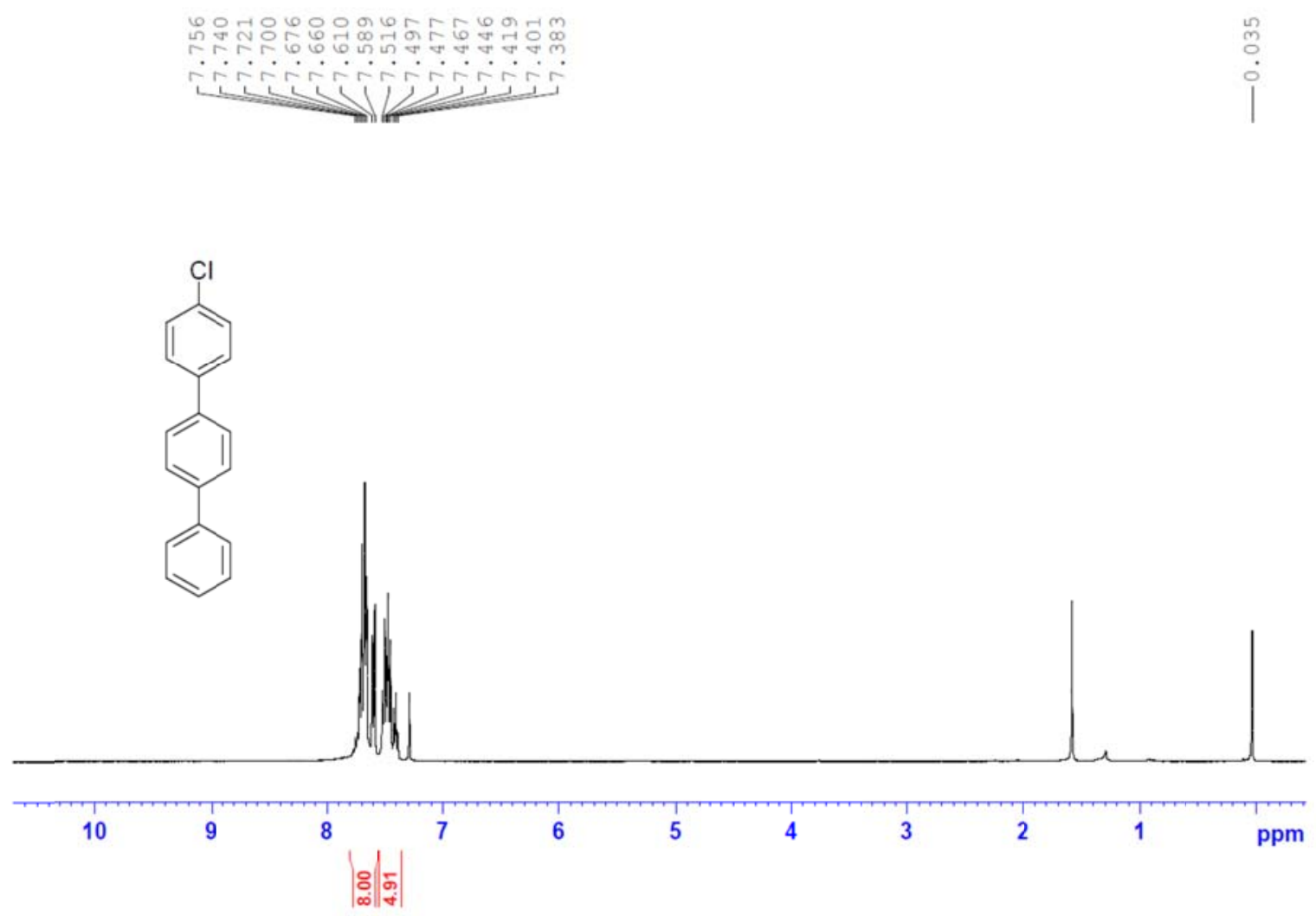

${ }^{1}$ H NMR of 4,4"'-dichloro-1,1': 4',1"'-terphenyl (DCTP).

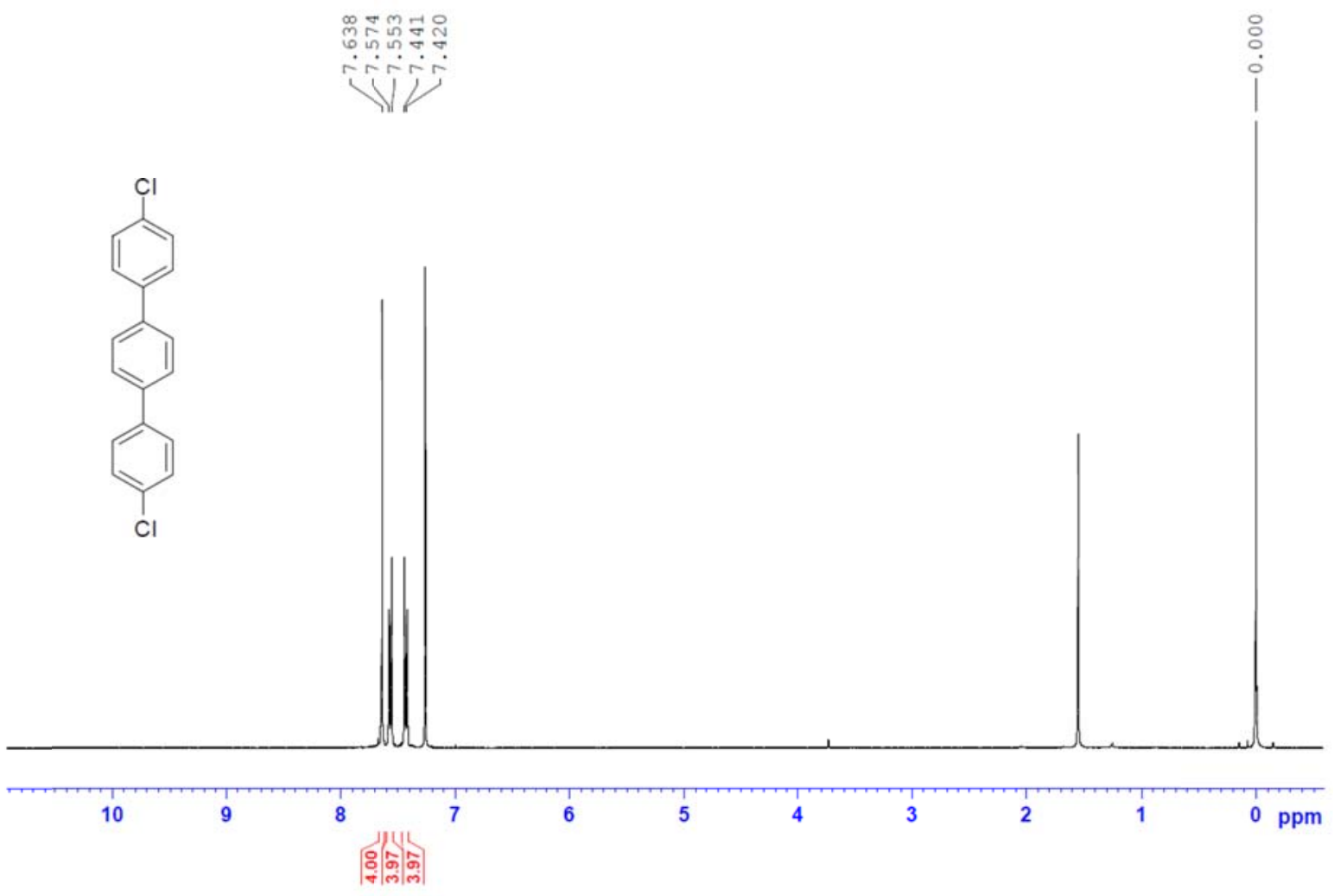


${ }^{1}$ H NMR of 4,4"'-dibromo-5'-(4-chlorophenyl)-1,1':3',1"'-terphenyl (DBCTP)
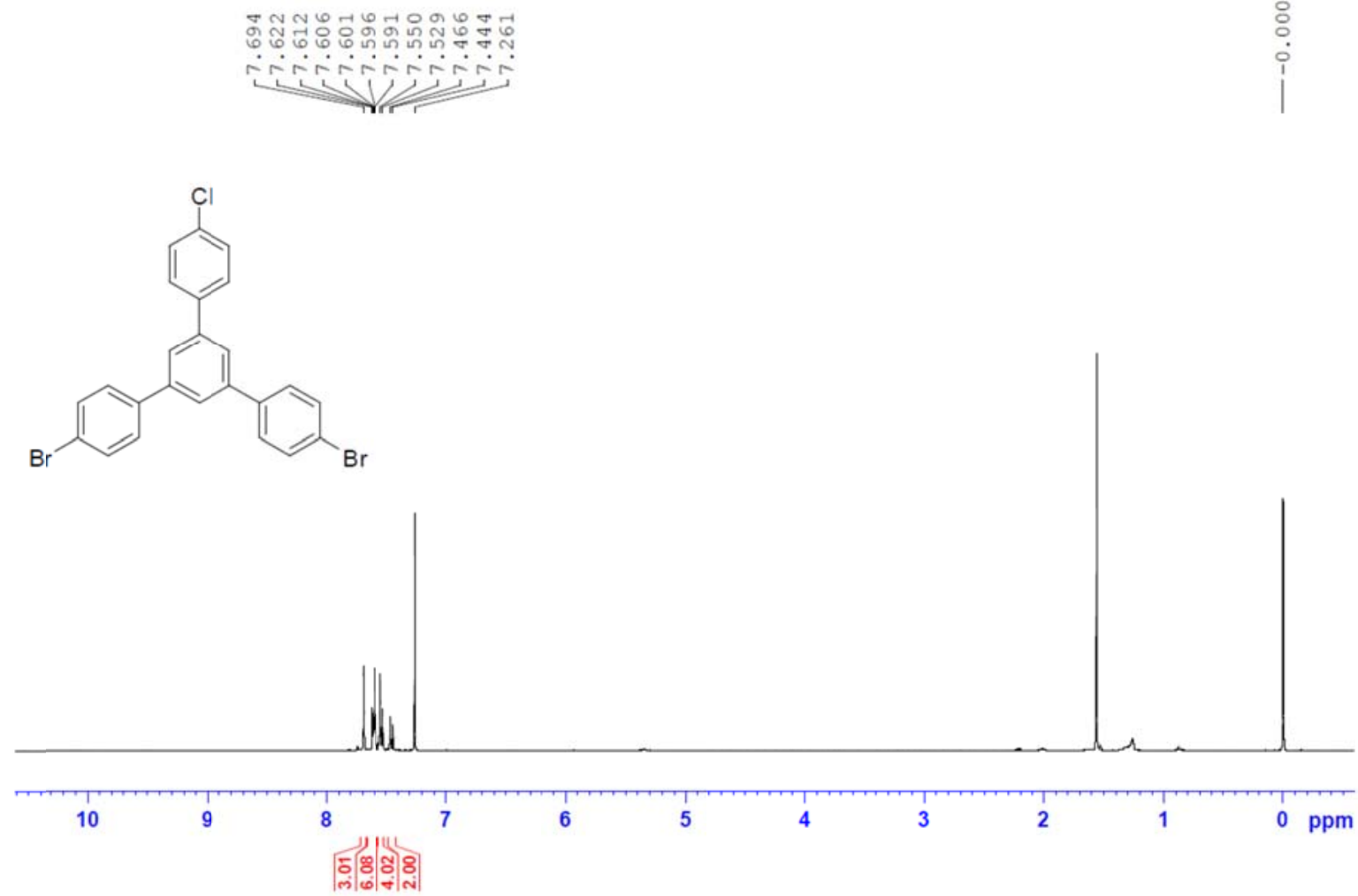

${ }^{13}$ C NMR of 4,4"'-dibromo-5'-(4-chlorophenyl)-1,1':3',1"'-terphenyl (DBCTP)

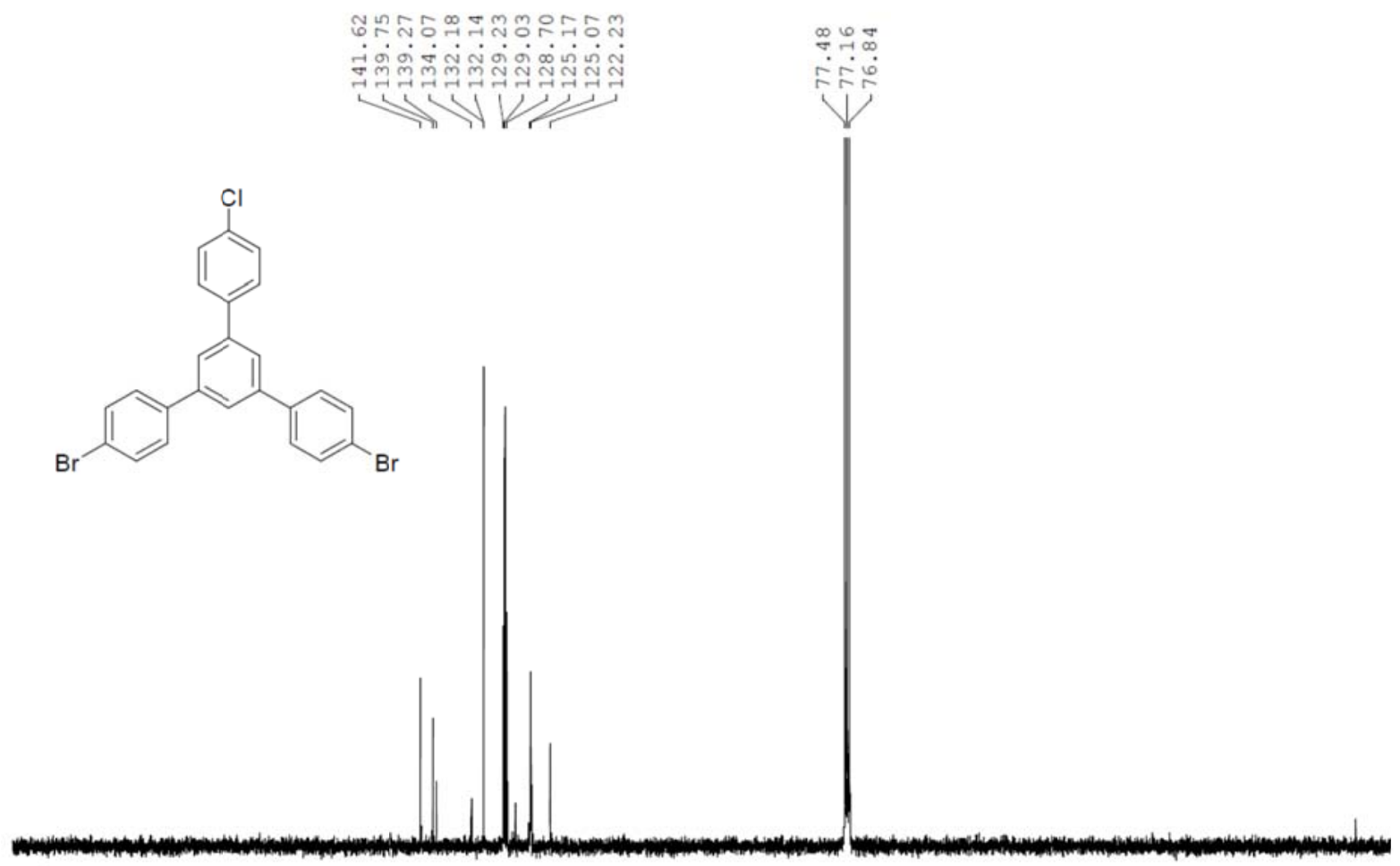

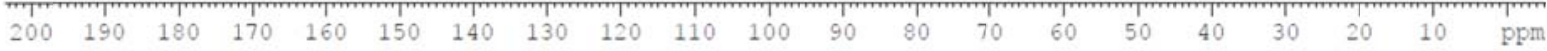

